\title{
PROSES BERPIKIR KREATIF MODIFIKATIF SISWA DALAM PENGAJUAN SOAL MATEMATIKA
}

\author{
Marhayati \\ UIN Maulana Malik Ibrahim Malang, Jalan Gajayana No. 50 Malang \\ marhayati@uin-malang.ac.id
}

\begin{abstract}
This study aims to describe the process of creative modification in mathematical problem posing. This research is descriptive. The research subjects reported were 7th grade students of Islamic Junior High School Surya Buana. The research subjects were 17 students. The subject used is Social Arithmetic. The submission of mathematical questions is applied in this study. The creative process of modification thinking in mathematical problem posing is a thought process that starts from the search for ideas originating from the provided information, possessed knowledge, daily experience, and / or from questions that have been previously proposed, then there are modification or addition of new information at once develop the form of a question that is submitted out of the given situation.
\end{abstract}

Keywords: creative thinking, modification, ideas, mathematical problem posing

\begin{abstract}
Abstrak
Penelitian ini bertujuan untuk mendeskripsikan proses berpikir kreatif modifikatif dalam pengajuan soal matematika. Penelitian ini merupakan deskriptif. Subjek penelitian yang dilaporkan merupakan siswa kelas 7 MTs Surya Buana. Subjek penelitian sebanyak 17 siswa. Pokok bahasan yang digunakan adalah Aritmatika Sosial. Pembelajaran yang diterapkan dalam penelitian ini adalah melalui pengajuan soal matematika. Proses berpikir kreatif modifikatif dalam pengajuan soal matematika adalah proses berpikir yang dimulai dari pencarian ide yang bersumber dari informasi yang diberikan, pengetahuan yang dimiliki, pengalaman seharihari, dan/atau dari soal yang sudah diajukan sebelumnya, kemudian adanya modifikasi atau penambahan informasi baru sekaligus pengembangan bentuk soal yang diajukan keluar situasi yang diberikan.
\end{abstract}

Kata Kunci: Berpikir Kreatif, Modifikatif, Ide, Pengajuan Soal Matematika

Pengajuan soal matematika sering dikaitkan dengan kreativitas (Kontorovich, Koichu, Leikin, \& Berman, 2011; Leung \& Silver, 1997; Siswono, 2010; Voica \& Mihaela, 2012; Yuan \& Sriraman, 2011; Zakaria \& Salleh, 2012). Kreativitas merupakan aktivitas kognitif menghasilkan ide-ide baru (Robert L. Solso, Otto H. Maclin, 2008:444). Kreativitas merupakan hasil dari berpikir kreatif.

Terdapat multilevel dalam tingkatan berpikir. Berpikir kreatif merupakan level tertinggi (Krulik, Rudnick, \& Milou, 2003). Hasil dari berpikir kreatif terkadang berbeda dari yang diharapkan. Siswa mampu berpikir kreatif dalam mengajukan pertanyaan atau soal ketika dapat mengeluarkan ideide baru yang unik dan berbeda.

Ide-ide kreatif dalam pengajuan soal muncul melalui proses/tahap kreatif. Proses kreatif menurut Wallas (dalam Sriraman \& Hadamard, 2009) melalui tahap persiapan, inkubasi, iluminasi, dan verifikasi. Pertama, tahap persiapan merupakan tahap yang penting sebab dalam tahap ini siswa berusaha untuk memahami masalah yang dihadapi. Jika siswa dapat memahami masalah yang dihadapi dengan baik, maka siswa melanjutkan dengan pencarian ide. Ide dapat diperoleh dari situasi yang diberikan dikaitkan dengan pengetahuan yang dimiliki. Kedua, tahap inkubasi yaitu mengendapkan informasi, meninggalkan sejenak masalah yang dihadapi. Tahap inkubasi dapat terjadi 
secara cepat ataupun secara lambat. Cepat artinya ide segera muncul. Namun apabila mengalami kesulitan untuk memperoleh ide, inkubasi terjadi cukup lama. Ketiga, tahap iluminasi yaitu muncul ide. Ide-ide dimunculkan dan saling dikaitkan. Keempat, tahap verifikasi yaitu menuliskan ide, memeriksa hasil penulisan ide. Memeriksa hasil penulisan ide apabila terjadi kesalahan ataupun digunakan untuk pengajuan soal selanjutnya.

Proses berpikir kreatif diperlukan dalam pengajuan soal matematika. Salah satu diantaranya adalah proses berpikir kreatif kombinatif (Marhayati, 2015). Diperlukan berpikir kreatif untuk menggali ide-ide sehingga menghasilkan soal yang unik. Penggalian ide, tidak hanya fokus pada situasi yang diberikan namun juga diperlukan perluasan ide. Proses berpikir kreatif modifikatif mempunyai ciri utama yaitu adanya perluasan ide sehingga adanya modifikasi ide keluar situasi/informasi yang diberikan (Marhayati, 2015). Jika soal yang diajukan siswa mengandung informasi baru dan mengembangkannya ke luar situasi yang diberikan maka hal ini menunjukkan sudah memenuhi aspek kelancaran, fleksibilitas, dan kebaruan (Marhayati \& Sa'dijah, 2018).

Memunculkan ide yag unik dalam pengajuan soal bukanlah hal yang mudah. Siswa kebanyakan cukup kreatif dalam pengajuan soal dan sedikit siswa yang kreatif (Marhayati \& Sa'dijah, 2018). Oleh karena itu, peneliti tertarik untuk meneliti tentang proses berpikir kreatif modifikatif dalam pengajuan soal matematika. Penelitian ini bertujuan untuk mendeskripsikan proses berpikir kreatif modifikatif dalam pengajuan soal matematika.

\section{METODE}

Penelitian ini merupakan deskriptif kualitatif. Subjek penelitian yang dilaporkan adalah siswa kelas 7 MTs Surya Buana Kelas 7. Subjek penelitian sebanyak 17 siswa. Pokok bahasan yang digunakan adalah Aritmatika Sosial. Pembelajaran yang diterapkan dalam penelitian ini adalah melalui pengajuan soal matematika. Siswa diminta untuk mengajukan soal tanpa harus menyelesaikan soal yang diajukan. Situasi/informasi yang diberikan kepada siswa untuk mengajukan soal merupakan situasi semi struktur (Stoyanova \& Ellerton, 1996). Siswa diberikan situasi/informasi yang digunakan sebagai acuan dalam mengajukan soal matematika.

Situasi/informasi yang diberikan dalam tugas pengajuan soal disajikan dalam bentuk tabel dan bentuk diagram. Menurut Christou, Mousoulides, Pittalis, \& Pitta-pantazi (2005) situasi yang disajikan dalam bentuk tabel dan diagram memerlukan proses berpikir penerjemahan (translating). Siswa harus memiliki kemampuan untuk membaca data dan menterjemahkan ke bentuk lain. Situasi/informasi yang diberikan berbentuk situasi terbuka. Dari situasi yang diberikan diharapkan siswa dapat mengeluarkan ide-ide kreatifnya dalam mengajukan soal dan mengembangkannya diluar situasi yang diberikan. Siswa diberi kebebasan untuk mengubah atau menambah informasi pada situasi yang diberikan. Situasi/informasi yang diberikan kepada siswa disajikan dalam Gambar 1 . 


\section{Situasi/Informasi}

Pada hari Minggu Zaki dan Ega mengunjungi Toko Sandang Murah yang menjual pakaian berupa baju, kaos, topi, dan kaos kaki. Mereka ingin membeli beberapa barang. Berikut ini daftar harga barang-barang yang terdapat di toko tersebut.

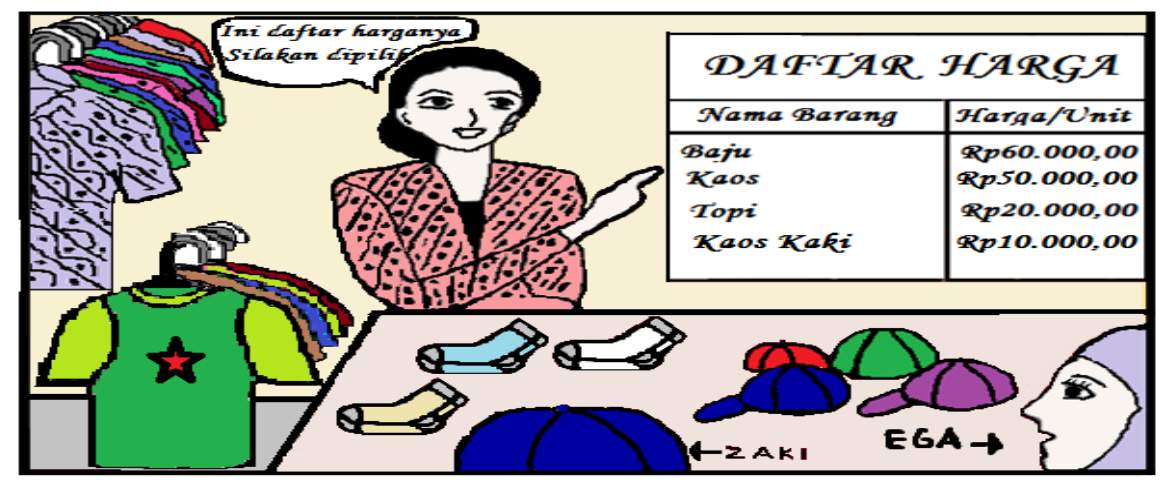

Setelah membeli barang mereka pulang ke rumah.

Tugas: Buatlah soal matematika sebanyak-banyaknya berdasarkan situasi/informasi/gambar di atas!

Gambar 1. Situasi/informasi yang diberikan kepada siswa

\section{HASIL DAN PEMBAHASAN}

Karakteristik siswa dalam pengajuan soal yaitu menambahkan informasi baru dan mengembangkan bentuk soal yang diajukan keluar situasi yang diberikan. Dari 17 subjek yang diteliti, ada 3 subjek yang menunjukkan ciri - ciri utama soal yang diajukannya mengarah ke berpikir kreatif modifikatif, sedangkan 14 subjek lainnya tidak. Dalam penelitian ini, ada 3 subjek yang menunjukkan ciri-ciri berpikir kreatif modifikatif, namun hanya 1 hasil kerja subjek (S1) yang didiskripsikan. Hasil kerja satu subjek yang didiskripsikan sudah mewakili kedua subjek lainnya. Data siswa dipaparkan, digambarkan struktur berpikir serta dilakukan analisis.

\section{Paparan dan Analisis Data Proses Berpikir Kreatif Siswa dalam Pengajuan Soal Matematika}

Persiapan awal yang dilakukan siswa untuk membuat soal adalah dengan membaca petunjuk pengerjaan dan melanjutkan dengan membaca situasi/informasi yang diberikan. Siswa membaca situasi yang diberikan guna memahami perintah tugas dan memahami keterkaitan antar unit-unit informasi yang disediakan (Pre(MS)). Siswa tidak membaca keseluruhan situasi yang diberikan sampai dengan selesai. Pernyataan siswa (S1) saat memahami situasi Toko Sandang Murah disajikan dalam Gambar 2. 
S1:Saya ingin membaca informasi : pada hari Minggu Zaki dan Ega mengunjungi Toko Sandang Murah yang menjual pakaian berupa baju, kaos, topi, dan kaos kaki. Mereka ingin membeli beberapa barang. Berikut ini daftar harga barang-barang yang terdapat di toko tersebut. Mungkin saya bisa mulai mengerjakan (S1 berhenti sebentar, kemudian mengucapkan "yak").

Gambar 2. Pernyataan S1 saat memahami situasi Toko Sandang Murah

S1 tidak mengalami kesulitan dalam memahami situasi/informasi yang diberikan, yang ditunjukkan dengan tidak membaca berulang-ulang. Hal ini menunjukkan struktur situasi yang diberikan sudah sesuai dengan struktur berpikir S1. S1 fokus pada tabel harga barang terutama pada topi yang berharga Rp20.000,00 (Pre(SI)). Pernyataan S1 saat mencari ide dari harga topi disajikan dalam Gambar 3.

S1: Topi harga 20.000, mungkin saya bisa membuat soal dengan topi tersebut

Gambar 3. Pernyataan S1 saat mencari ide dari harga topi

S1 menyintesis ide (Pre(SI)) yaitu mengaitkan situasi yang diberikan dengan pengetahuan atau pengalaman yang dimilikinya yaitu mengenai pelajaran kelas 3 SD dan pengalaman waktu membeli kaos. Hal tersebut diketahui dari hasil wawancara. Petikan wawancara Peneliti (P) dengan S1 mengenai sumber ide tentang diskon disajikan dalam Gambar 4.

P: Waktu dapat ide kamu lagi apa?

S1: Saya habis memikirkan kelas 3 SD, cerita ini berhubungan dengan pengalaman saya waktu SD. Dulu waktu saya beli kaos, dapat diskon

Gambar 4. Petikan wawancara Peneliti $(P)$ dengan $S 1$ mengenai sumber ide tentang diskon

S1 memutuskan untuk membuat soal tentang harga topi namun menemui sedikit kebingungan dan berhenti/diam sejenak ini menunjukkan bahwa S1 kembali mengalami inkubasi (Ink1). S1 berusaha mendapatkan ide untuk membuat soal. Pernyataan S1 saat mengalami kebingungan disajikan dalam Gambar 5.

S1: Di sini saya agak sedikit bingung em... (S1 berhenti sejenak).

Gambar 5. Pernyataan S1 saat mengalami kebingungan

S1 selanjutnya mengalami iluminasi yaitu mendapat ide utama mengenai pembelian barang. Guna mewujudkan ide utama tersebut S1 mendapatkan ide pendukung yaitu menentukan jenis barang yang dibeli dan banyaknya pembelian. Jenis barang yang dibeli yaitu topi dan kaos. Banyaknya barang yang dibeli topi 3 buah dan kaos 7 buah (Ilu1(MI)). Pernyataan S1 tentang ide pembelian topi dan kaos disajikan dalam Gambar 6.

S1 : Zaki membeli 3 buah topi dengan harga 20000/biji, sedangkan Ega membeli kaos yang berjumlah 7 buah.

Gambar 6. Pernyataan S1 tentang ide pembelian topi dan kaos 
S1 memverifikasi ide dengan menuliskannya pada lembar penyelesaian (Ver1(II)). Hasil verifikasi 1 (Ver1(II)) S1 pada soal ke-1 disajikan dalam Gambar 7.

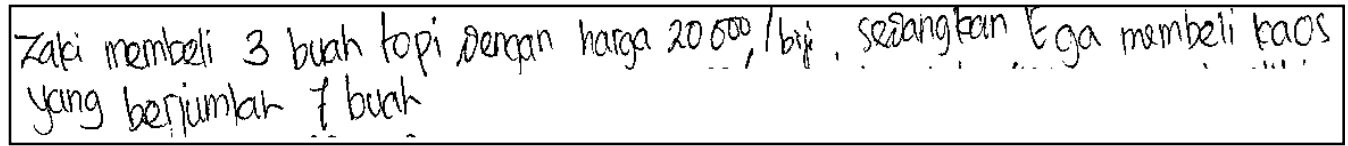

Gambar 7. Hasil verifikasi 1 S1 pada soal ke-1

S1 membaca kembali tabel harga yang disediakan, ini menunjukkan terjadi inkubasi lagi (Ink2). S1 berusaha mencari ide selanjutnya dengan membaca kembali daftar harga barang. Pernyataan S1 saat membaca daftar harga kaos disajikan dalam Gambar 8.

S1 : Daftar harga kaos 50000/unit.

Gambar 8. Pernyataan S1 saat membaca daftar harga kaos

S1 mengalami iluminasi yaitu mendapatkan ide menambahkan daftar harga kaos 50000/unit (Ilu2(MI)). Selanjutnya S1 mengembangkan ide dan memperoleh ide baru yaitu mengandaikan uang yang dimiliki sebesar Rp175000,00, adanya diskon sebesar 5\% untuk pembelian kaos, dan ditanyakan mengenai banyaknya kaos yang dibeli dengan uang dimiliki. Pernyataan S1 pernyataan S1 mengenai ide menambahkan uang yang dibawa belanja dan besarnya diskon disajikan dalam Gambar 9.

S1: ... dengan harga 50000/unit. Kebetulan uang yang dimiliki Ega sebesar 175000 diantara 4 barang yang dijual mempunyai beragam diskon kebetulan diskon satu unit kaos sebesar 5\% agar uang Ega mencukupi berapa kaos yang harus dia beli?

Gambar 9. Pernyataan S1 mengenai ide menambahkan uang yang dibawa belanja dan besarnya diskon

Kemudian S1 memverifikasi ide (Ver2(II)) dengan menuliskan ide tersebut pada lembar penyelesaian. Hasil verifikasi 2 (Ver2(II)) disajikan dalam Gambar 10.

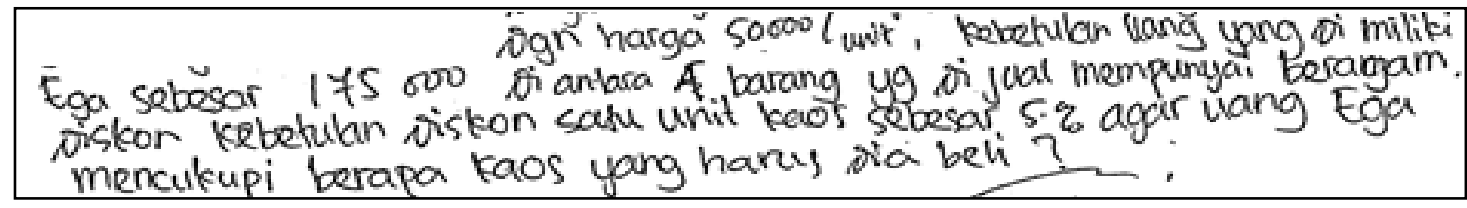

Gambar 10. Hasil verifikasi 2 (Ver2(II)) S1 pada soal ke-1

Selesai membuat soal, S1 tidak memeriksa kembali soal yang sudah dibuatnya. S1 tidak menyadari jika soal yang dibuatnya terdapat kelebihan informasi yang sebenarnya tidak dibutuhkan yaitu mengenai pembelian 3 kaos dan 7 topi. Sebab pertanyaan yang diajukan adalah agar uang mencukupi berapa banyak topi yang dapat dibeli. Ini menunjukkan ide S1 berubah selama proses pengajuan soal. Hasil kerja S1 pada soal ke-1 disajikan secara lengkap dalam Gambar 11. 


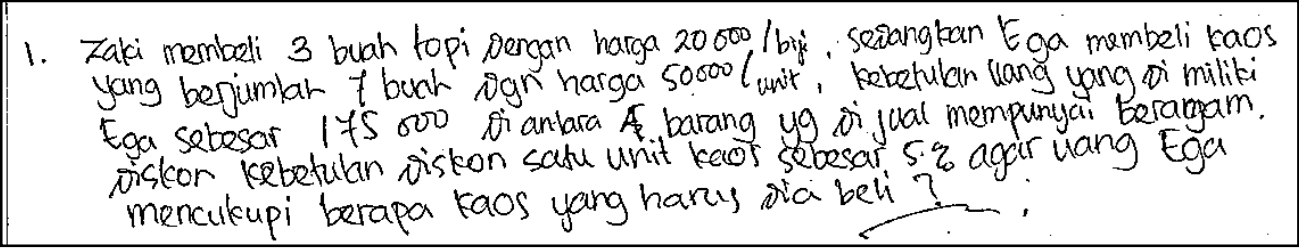

Gambar 11. Hasil kerja S1 pada soal ke-1

Soal ke-1 yang dibuat S1 mengandung informasi kuantitatif baru mengenai banyaknya barang yang dibeli yaitu 3 topi, 7 kaos, uang yang dimiliki sebesar 175.000 dan diskon sebesar 5\%.

Persiapan pembuatan soal ke-2, dilakukan S1 dengan membaca situasi Toko Sandang Murah (Pre(SI)). S1 berusaha mendapatkan ide membuat soal. Pernyataan S1 saat memahami situasi Toko Sandang Murah disajikan dalam Gambar 12.

S1: Kemudian saya ingin membaca kembali cerita untuk mencari soal yang berikutnya. Mungkin di sini saya bisa menambahkan informasi yang bisa berpotensi untuk menjadi sebuah soal. (S1 diam sejenak).

Gambar 12. Pernyataan S1 saat memahami situasi Toko Sandang Murah

S1 berusaha mengaitkan situasi yang diberikan dengan pengetahuan atau pengalaman yang dimiliki. S1 memandang situasi/informasi dari sudut pandang yang berbeda yaitu perjalanan menuju ke Toko Sandang Murah. S1 mempunyai ide yaitu membuat soal mengenai jarak, waktu, dan kecepatan. Berikut petikan wawancara Peneliti (P) dengan S1 tentang sumber ide soal ke-2 yaitu jarak, waktu, dan kecepatan disajikan dalam Gambar 13.

P: Kalo soal yang ke 2 dapat ide dari mana?

S1: Di sini saya teringat dulu waktu kelas 5 ada pelajaran kecepatan dan waktu. Saya ingin menambahkan kecepatan saja.

Gambar 13. Petikan wawancara Peneliti $(P)$ dengan S1 tentang sumber ide soal ke-2

Soal kedua ini tampaknya sudah ada dalam skema berpikir S1 sebab inkubasi terjadi dengan cepat. S1 tidak berhenti/diam sejenak langsung muncul ide. Inkubasi ditandai dengan membaca kembali situasi yang diberikan itu pun dilakukan dengan cepat.

S1 mengalami iluminasi, kemudian mulai membangun ide (Ilu(MI)) dengan menambahkan informasi baru pada situasi Toko Sandang Murah. S1 memunculkan ide pertama yaitu menambahkan waktu berangkat dari rumah pukul 11.25, menambahkan jarak dari rumah ke Toko Sandang Murah 5 $\mathrm{km}$ dan kecepatan kendaraan $25 \mathrm{~km} / \mathrm{jam}$. Pernyataan S1 tentang informasi baru yang ditambahkan untuk soal ke-2 disajikan dalam Gambar 14.

S1: Tambahan informasi: Zaki dan Ega berangkat pukul 11.25 mereka berangkat menuju Toko Sandang Murah yang jarak dari rumah mereka sekitar $5 \mathrm{~km}$ mereka pergi kesana menggunakan motor dengan kecepatan $25 \mathrm{~km} / \mathrm{jam}$. Dari informasi tambahan ini saya bisa membuat satu soal lagi.

Gambar 14. Pernyataan S1 tentang informasi baru yang ditambahkan 
Hasil tambahan informasi S1 pada soal ke-2 disajikan dalam Gambar 15.

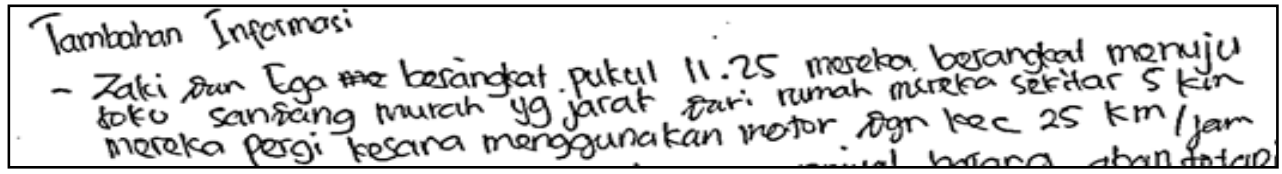

Gambar 15. Tambahan informasi S1 pada soal ke-2

Setelah menambahkan informasi baru, S1 membuat soal ke-2 yaitu bila kecepatan kendaraan menuju Toko Sandang Murah $25 \mathrm{~km} / \mathrm{jam}$, jarak $5 \mathrm{~km}$, dan waktu berangkat pukul 11.25 pada pukul berapa tiba di Toko Sandang Murah. Pernyataan S1 saat memunculkan ide tentang waktu tiba di Toko Sandang Murah disajikan dalam Gambar 16.

S1 : Apabila mereka menuju Toko Sandang Murah dengan kecepatan 25 km/jam dan dengan jarak $5 \mathrm{~km}$ dan mereka berangkat pada pukul 11.25, pada pukul berapakah mereka sampai di sana?

Gambar 16. Pernyataan S1 tentang ide waktu tiba di Toko Sandang Murah

Akhirnya S1 memverifikasi ide dengan menuliskannya pada lembar penyelesaian (Ver(II)). Selesai membuat soal S1 tidak memeriksa lagi soal yang dibuatnya. Hasil kerja S1 pada soal ke-2 disajikan dalam Gambar 17.

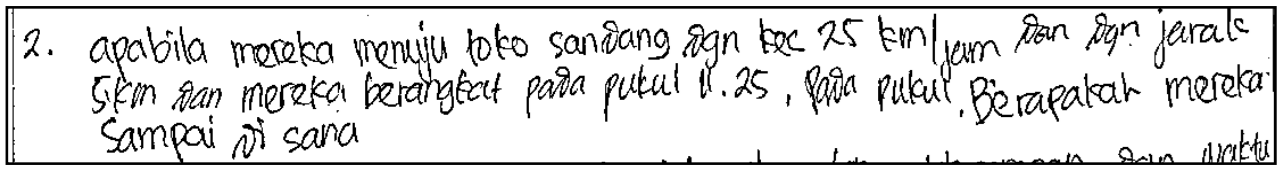

Gambar 17. Hasil kerja S1 pada soal ke-2

Soal ke-2 yang dibuat S1 mengandung informasi kuantitatif baru yaitu kecepatan $25 \mathrm{~km} / \mathrm{jam}$, jarak $5 \mathrm{~km}$ dan waktu berangkat pukul 11.25. S1 berhasil mengembangkan soal yang dibuatnya keluar situasi yang diberikan. Ini menunjukkan adanya kebaruan ide karena dapat mengaitkan situasi yang diberikan dengan pengalaman/pengetahuan yang dimilikinya.

Persiapan pembuatan soal ke-3 dilakukan S1 dengan fokus pada informasi baru yang telah ditambahkan pada soal ke-2. Pernyataan S1 saat mencermati informasi baru yang telah ditambahkan pada soal ke-2 disajikan dalam Gambar 18.

S1: Saya ingin membuat satu soal lagi untuk cerita mungkin dua atau tiga soal lagi. Saya ingin (S1 berhenti sejenak, kemudian melanjutkan membuat soal).

Gambar 18. Pernyataan SI saat mencermati informasi baru yang telah ditambahkan pada soal ke-2

S1 melakukan persiapan mengajukan soal ke-3 dengan fokus pada informasi baru yang telah ditambahkan dan digunakan pada soal ke-2. Di sini S1 menyintesis ide dengan mengaitkan informasi pada soal ke-2 dan informasi baru yang ditambahkan. S1 masih mengaitkan informasi baru yang telah ditambahkan pada soal ke-2 dengan mengubah kecepatan kendaraan dan ada jeda waktu beristirahat 
(Pre(SI)) hal ini dapat dilihat dari hasil pekerjaan S1.

S1 mengalami inkubasi, hal ini ditandai saat S1 berhenti sejenak (Ink1). S1 berusaha untuk mencari ide baru yang akan ditambahkan pada soal ke-3. Kemudian S1 mengalami iluminasi yaitu muncul ide baru berdasarkan informasi pada soal ke-2 yaitu ide membuat soal mengenai lamanya waktu yang diperlukan untuk sampai di Toko Sandang Murah apabila dalam perjalanan berhenti sejenak (Ilu1(MI)). S1 mendapatkan ide tentang waktu berhenti untuk sarapan selama 30 menit. Ide lain yaitu mengubah kecepatan kendaraan menjadi 40km/jam setelah perjalanan $3 \mathrm{~km}$ dari rumah. Pernyataan S1 tentang ide waktu berhenti dan perubahan kecepatan kendaraan disajikan dalam Gambar 19.

S1: Apabila Zaki dan Ega berhenti di tengah jalan untuk sarapan dengan waktu 30 menit kemudian setelah mereka sarapan mereka kembali meluncur untuk pergi ke tujuan akan tetapi di jarak $3 \mathrm{~km}$ dari rumah mereka Zaki menambah kecepatan kelajuan sepeda motornya dengan kecepatan $40 \mathrm{~km} / \mathrm{jam}$.

Gambar 19. Pernyataan S1 tentang ide waktu berhenti dan perubahan

Tahap berikutnya S1 memverifikasi ide dengan menuliskan pada lembar penyelesaian (Ver1(II)). Hasil verifikasi 1 (Ver1(II)) S1 pada soal ke-3 disajikan dalam Gambar 20.

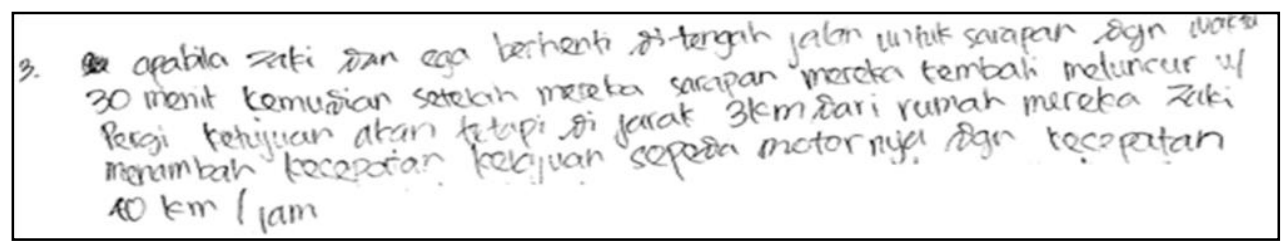

Gambar 20. Verifikasi 1 (Verl(II)) S1 pada soal ke-3

S1 mengalami kesulitan melanjutkan mengajukan soal. S1 berhenti sejenak ini menunjukkan S1 mengalami inkubasi (Ink2) kembali. Pernyataan S1 saat mengalami kesulitan disajikan dalam Gambar 21.

S1: (S1 berhenti sejenak) pikiran saya tidak fokus, entah mengapa saya kesulitan dalam membuat soal.

Gambar 21. Pernyataan S1 saat mengalami kesulitan

Kemudian S1 mendapatkan ide untuk menambahkan informasi baru (Ilu(MI)) yaitu menambahkan jarak yang ditempuh kurang $2 \mathrm{~km}$ lagi dari toko. Pernyataan S1 tentang ide jarak tempuh kurang $2 \mathrm{~km}$ dari toko disajikan dalam Gambar 22.

$\mathrm{S} 1:$ (...menuju tujuan yang tinggal $2 \mathrm{~km}$ berapa lamakah waktu yang dibutuhkannya dalam menuju tempat tujuan.

Gambar 22. Pernyataan S1 tentang ide jarak tempuh kurang $2 \mathrm{~km}$ dari toko

Akhirnya S1 memverifikasi ide dengan menuliskan pada lembar penyelesaian (Ver2(II)). Selesai mengajukan soal ke-3, S1 tidak memeriksa kembali soal yang sudah dibuatnya. Hasil verifikasi 2 (Ver2(II)) pada soal ke-3 disajikan dalam Gambar 23. 


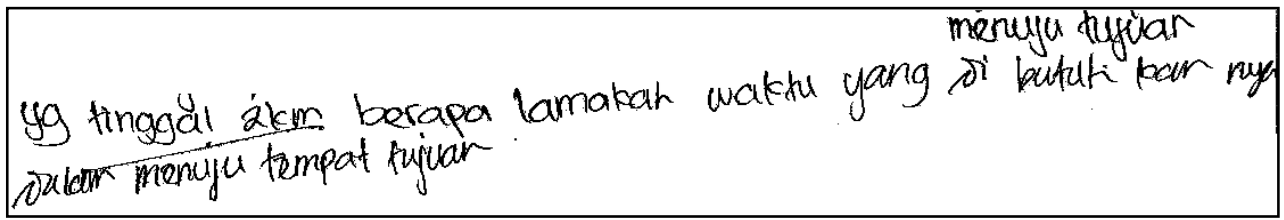

Gambar 23. Verifikasi 2 (Ver2(II)) S1 pada soal ke-3

Hasil kerja S1 pada soal ke-3 secara lengkap disajikan dalam Gambar 24.

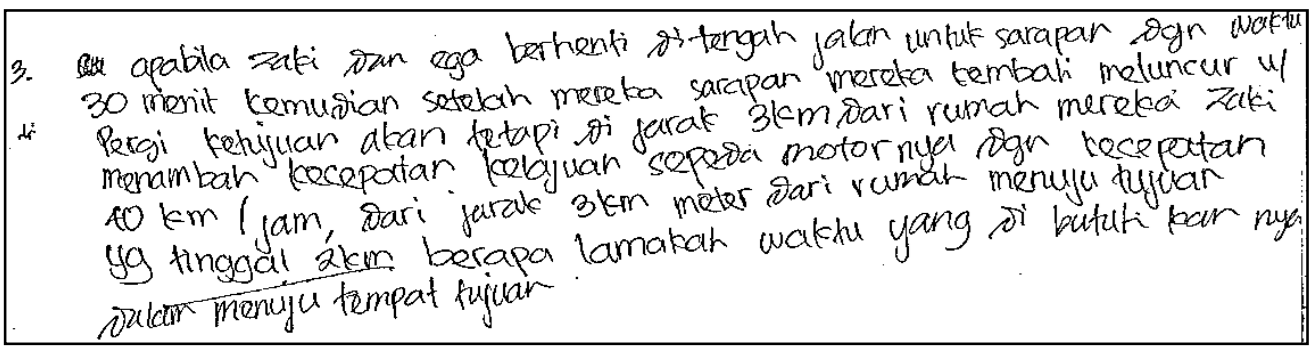

Gambar 24. Hasil kerja S1 pada soal ke-3

Soal ke-3 yang dibuat S1 mengandung informasi kuantitatif baru yaitu waktu berhenti untuk sarapan 30 menit, jarak 3km, kecepatan berubah $40 \mathrm{~km} / \mathrm{jam}$. S1 berhasil mengembangkan soal yang dibuat berdasarkan soal sebelumnya. Ini menunjukkan adanya keaslian dan kebaruan ide sehingga berhasil membuat soal yang unik/berbeda.

S1 merasa kurang puas dengan soal ke-3 yang telah dibuatnya, hal ini kemungkinan karena beberapa kali mengalami kebuntuan sehingga berhenti sejenak kemudian dilanjutkan kembali. Pernyataan S1 mengenai ketidakpuasan tentang soal ke-3 disajikan dalam Gambar 25.

S1 : Saya telah membuat soal ketiga, mungkin dari soal ketiga saya kurang maksimal dalam mengerjakannya.

Gambar 25. Pernyataan S1 mengenai ketidakpuasan tentang soal ke-3

Persiapan pembuatan soal ke-4 dilakukan S1 dengan fokus pada situasi Toko Sandang Murah. S1 mengaitkan situasi Toko Sandang Murah dengan kenyataan bahwa toko tak hanya menjual barang namun juga membeli barang untuk dijual kembali (Pre(SI). Pernyataan S1 saat mencari ide tentang toko yang tidak hanya menjual barang namun juga membeli barang disajikan dalam Gambar 26.

$\mathrm{S} 1$ : Di sini saya akan menulis tambahan informasi tersebut ( $\mathrm{S} 1$ berhenti/diam). Inti dari tambahan informasi adalah toko sandang murah tidak hanya menjual barang tetapi juga membeli barang yang ingin dijual oleh seseorang.

Gambar 26. Pernyataan S1 saat mencari ide tentang toko tidak hanya menjual barang namun juga membeli barang

Tahap berikutnya terjadi inkubasi hal ini ditunjukkan S1 dengan berhenti atau diam sejenak (Ink1). Selanjutnya S1 mengalami iluminasi yaitu mendapatkan ide untuk menambahkan informasi baru mengenai Toko Sandang Murah juga membeli barang yang dijual masyarakat dengan separuh harga dari yang dijual toko tersebut (Ilu1(MI)). Pernyataan S1 tentang ide menambahkan informasi 
baru disajikan dalam Gambar 27.

S1 : Toko Sandang Murah juga membeli barang yang dijual masyarakat dengan harga separuh harga barang yang baru (yang sejenis).

Gambar 27. Pernyataan S1 tentang ide menambahkan informasi baru

Hasil tambahan informasi baru S1 untuk soal ke-4 disajikan dalam Gambar 28.

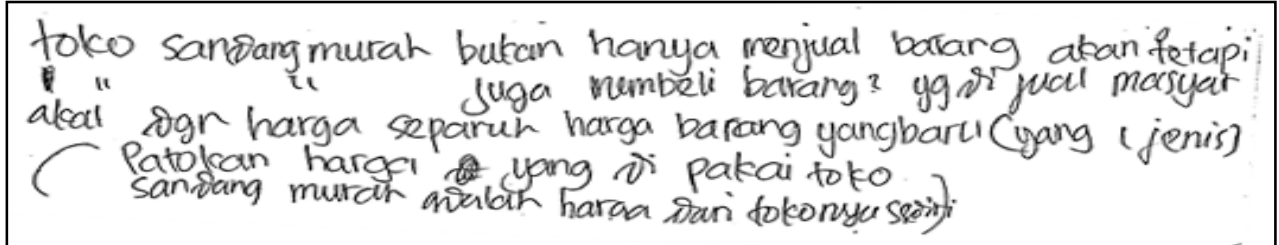

Gambar 28. Tambahan informasi S1 untuk soal ke-4

S1 mengalami inkubasi terjadi dengan cepat. S1 mengamati tabel harga barang. S1 fokus pada topi, kaos, dan kaos kaki. Selanjutnya S1 mengembangkan ide yaitu menambahkan informasi kuantitatif baru berupa banyaknya barang yang akan dijual ke Toko Sandang Murah. Banyaknya topi dan kaos yang dijual masing-masing 7 dan kaos kaki 16 pasang (Ilu1(MI)). Pernyataan S1 tentang ide banyaknya barang yang akan dijual disajikan dalam Gambar 29.

S1 : Apabila Zaki menjual topi, kaos dengan jumlah 7 masing-masing barang dan juga kaos kaki dengan jumlah 16 pasang.

Gambar 29. Pernyataan S1 tentang ide banyaknya barang yang akan dijual

Kemudian S1 memverifikasi ide dengan menuliskannya pada lembar penyelesaian (Ver1(II)). Hasil verifikasi disajikan dalam Gambar 30.

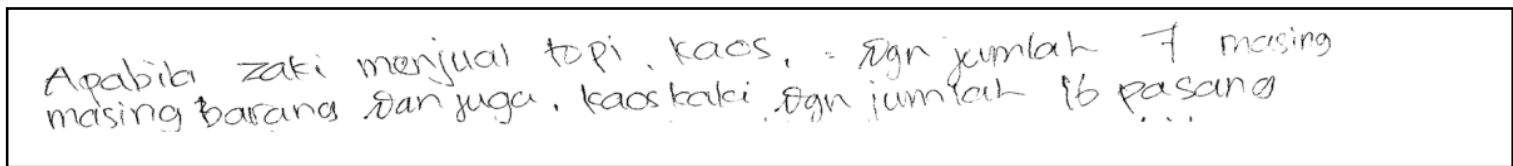

Gambar 30. Verifikasi 1 (Verl(II)) S1 pada soal ke-4

S1 menggunakan informasi yang telah ditambahkan untuk membuat pertanyaan mengenai uang yang akan didapat apabila barang dibeli dengan harga setengahnya dari harga yang terdapat di Toko Sandang Murah (Ilu2(II)). Pernyataan S1 tentang ide barang yang dibeli separuh harga disajikan dalam Gambar 31. 


\section{$\mathrm{S} 1$ : Berapakah uang yang didapatkan Zaki apabila barang mereka dibeli dengan harga separuhnya dari harga barang di Toko Sandang Murah sendiri? Tentukan perolehan yang didapatkan Zaki.}

Gambar 31. Pernyataan S1 tentang ide barang yang dibeli separuh harga

Akhirnya S1 melanjutkan memverifikasi ide dengan menuliskannya pada lembar penyelesaian. Hasil verifikasi 2 (Ver2(II)) S1 pada soal ke-4 disajikan dalam Gambar 32.

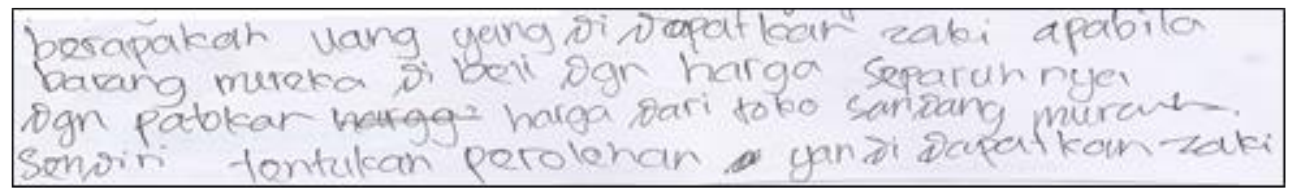

Gambar 32. Verifikasi 2 (Ver2(II)) S1 pada soal ke-4

Sewaktu menuliskan ide, S1 melakukan pemeriksaan terhadap soal yang sedang dibuat. Hal ini ditunjukkan dengan adanya coretan-coretan yang dimaksudkan untuk mengoreksi kesalahan penulisan atau kata-kata yang tidak tepat. Hasil kerja S1 pada soal ke-6 secara lengkap disajikan dalam Gambar 33.

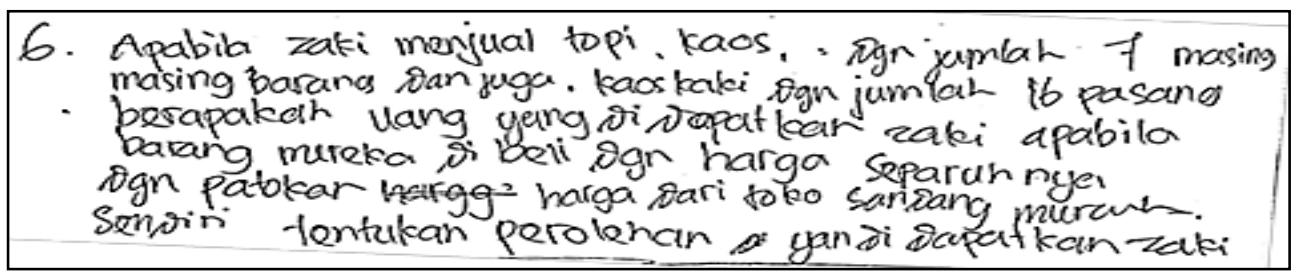

Gambar 33. Hasil kerja S1 pada soal ke-4

Soal ke-4 mengandung informasi kuantitatif baru mengenai banyaknya barang topi dan kaos 7, kaos kaki 16 pasang. Informasi baru yang ditambahkan yaitu barang dibeli separuh dari harga di Toko Sandang Murah. Ide membuat soal seperti ini menunjukkan adanya kebaruan ide dan unik.

Berdasarkan paparan dan analisis data, struktur berpikir S1 ketika mengajukan soal matematika digambarkan seperti dalam Gambar 34.

Struktur berpikir S1 dalam membuat soal menggunakan struktur pengetahuan dan pengalaman sehari-hari yang dimilikinya. S1 berhasil mengaitkan situasi/informasi yang diberikan dengan pengalaman/pengetahuan yang dimilikinya dan menuangkan ide-ide kreatif nya dalam pengajuan soal. 


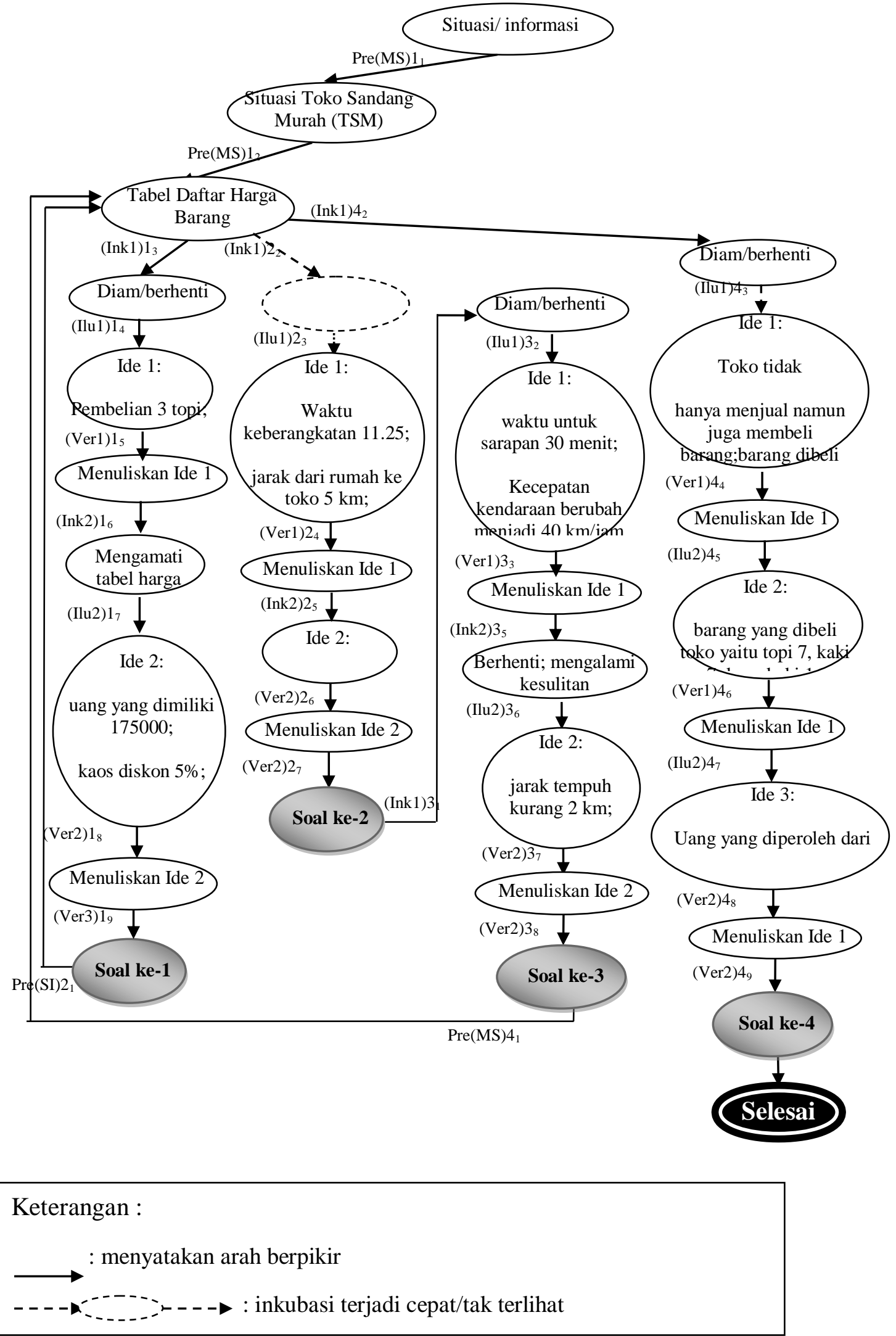

Gambar 34. Struktur berpikir S1 dalam pengajuan soal matematika 
S1 membuat soal yang memenuhi kriteria kreatif kefasihan (kelancaran), fleksibilitas (keluwesan), dan kebaruan (kebaruan ide). Kriteria kreatif terpenuhi sebab S1 membuat soal sebanyak mungkin sesuai dengan perintah tugas. Kriteria keluwesan terpenuhi sebab S1 membuat tipe soal yang berbedabeda dan menambahkan informasi baru. Kriteria kebaruan terpenuhi sebab S1 mengajukan soal yang berbeda dan unik serta mengembangkan soal yang diajukannya ke luar situasi yang diberikan terutama pada soal ke-2, 3, dan 5. Hal ini menunjukkan terjadi perubahan ide-ide (modify) (Ma, 2006). Oleh sebab itu berpikir kreatif $S 1$ dikategorikan ke dalam berpikir kreatif modifikatif.

Hasil analisis data menunjukkan bahwa persiapan yang dilakukan S1 guna memahami situasi yang diberikan dalam pengajuan soal matematika adalah membacanya (Pre(MS)). S1 membaca situasi Toko Sandang Murah terutama tabel harga barang kemudian langsung membuat soal ke-1. Soal ke-2 dan ke-3 dibuat S1 tidak berdasarkan situasi yang diberikan namun berdasarkan pengetahuan dan pengalaman yang dimiliki. S1 memperluas berpikirnya ke luar situasi yang diberikan. S1 mengaitkan situasi yang diberikan dengan pengetahuan seperti pembelian atau penjualan buah/barang, diskon, kecepatan, jarak, waktu, bruto dan netto. Pengalaman yang dikaitkan S1 seperti perjalanan dan waktu yang ditempuh untuk berbelanja, pembelian buah dalam kemasan tong, dan kenyataan bahwa toko tidak hanya menjual barang namun juga membeli barang (Pre(SI)).

Inkubasi terjadi pada setiap pengajuan soal. Inkubasi terjadi beberapa kali pada setiap pengajuan soal. Namun ada juga inkubasi yang terjadi dengan cepat sehingga S1 tidak memerlukan waktu lama dan tidak berhenti sejenak/diam untuk mendapatkan ide. Ketika pemikiran tidak dapat menemukan solusi/ide secara terus menerus sehingga muncul tindakan untuk menghentikan atau meninggalkan sejenak kegiatan yag sedang dilakukan biasanya dalam suasana yang santai, hal ini menunjukkan sedang inkubasi (Wang, 2009). Inkubasi dialami S1 berusaha mendapatkan ide untuk membuat soal dan saat berusaha mencari ide baru dari ide yang sudah muncul sebelumnya.

Iluminasi muncul setelah terjadi inkubasi. Iluminasi ditandai dengan munculnya ide (Wallas dalam Herring, Jones, \& Bailey, 2009). S1 membangun ide secara bertahap. Begitu mendapatkan ide langsung di verifikasi dengan menuliskannya di lembar penyelesaian. S1 mendapatkan ide untuk menambahkan informasi baru khususnya informasi kuantitatif pada setiap soal yang diajukannya. Pada soal ke-2, 3, 5 dan 6, S1 menambahkan informasi kuantitatif yang berbeda sehingga soal yang dibuat menjadi berbeda. Berpikir S1 berkembang mulai dari yang sederhana ke yang lebih kompleks. Sebab pada soal ke-1, S1 membuat soal masih berdasarkan situasi yang diberikan. Soal ke-2 dan ke-3, dibuat $\mathrm{S} 1$ berdasarkan pengetahuan, pengalaman yang dimiliki dan menggunakan konteks ceritanya saja.

Verifikasi ide terjadi secara bertahap. Setelah muncul ide, S1 langsung memverifikasi dengan menuliskannya di lembar penyelesaian. Inkubasi terjadi kembali diikuti iluminasi dilanjutkan dengan verifikasi ide sampai selesai pengajuan soal. Pemeriksaan soal yang sudah dibuat dilakukan secara bertahap setelah penulisan ide. Selesai semua mengajukan soal, S1 tidak memeriksa kembali. 


\section{KESIMPULAN}

Proses berpikir kreatif modifikatif dalam pengajuan soal mempunyai ciri yaitu adanya modifikasi atau penambahan informasi baru sekaligus mengembangkan bentuk soal yang diajukan ke luar dari situasi yang diberikan. Pencarian ide untuk pengajuan soal matematika bersumber dari situasi/informasi yang diberikan, pengetahuan yang dimiliki, pengalaman sehari-hari, dan/atau soal yang sudah diajukan sebelumnya. Adanya modifikasi atau perluasan ide keluar situasi/informasi yang diberikan. Oleh karena itu, proses berpikir kreatif modifikatif dalam pengajuan soal matematika adalah proses berpikir yang dimulai dari pencarian ide yang bersumber dari informasi yang diberikan, pengetahuan yang dimiliki, pengalaman sehari-hari, dan/atau dari soal yang sudah diajukan sebelumnya, kemudian adanya modifikasi atau penambahan informasi baru sekaligus mengembangkan bentuk soal yang diajukan keluar situasi yang diberikan.

\section{DAFTAR PUSTAKA}

Christou, C., Mousoulides, N., Pittalis, M., \& Pitta-pantazi, D. (2005). An empirical taxonomy of problem posing processes An Empirical Taxonomy of Problem Posing Processes. Zentralblatt Fur Diktatik Der Mathematik, 37(3), 149-158. https://doi.org/10.1007/s11858-005-0004-6

Herring, S. R., Jones, B. R., \& Bailey, B. P. (2009). Idea Generation Techniques among Creative Professionals. Proceedings of the 42nd Hawaii International Conference on System Sciences, 110. Manoa, Honolulu: HI, USA.

Kontorovich, I., Koichu, B., Leikin, R., \& Berman, A. (2011). Indicators of creativity in mathematical problem posing: how indicative are they? (L. S. \& V. M. Avotina, D. Bonka, H. Meissner, L. Ramana, Ed.). Latvia: Latvia University.

Krulik, S., Rudnick, J., \& Milou, E. (2003). Teaching Mathematics in Middle School: A Practical Guide. USA: Pearson Education.

Leung, S. S., \& Silver, E. A. (1997). The Role of Task Format , Mathematics Knowledge, and Creative Thinking on the Arithmetic Problem Posing of Prospective Elementary School Teachers. Mathematics Education Research Journal, 9(1), 5-24.

Ma, H. (2006). A Synthetic Analysis of the Effectiveness of Single Components. Creativity Research Journal, 18(4), 435-446.

Marhayati. (2015). Karakteristik proses berpikir kreatif siswa dalam pengajuan soal matematika. Universitas Negeri Malang.

Marhayati, \& Sa'dijah, C. (2018). Kemampuan berpikir kreatif matematika siswa ditinjau dari aspek kefasihan, fleksibilitas, dan kebaruan. Jurnal Pendidikan Dan Pembelajaran Dasar, 10(2), 111117.

Siswono, T. Y. E. (2010). Leveling Students' Creative Thinking in Solving and Posing Mathematical Problem. Journal Mathematics Education, 1(1), 17-40.

Solso, R. L., Maclin, O. H., \& Maclin, M. K. (2008). Psikologi Kognitif (Edisi 8; M. R. \& K. 
Batuadji, Ed.). Jakarta: Penerbit Erlangga.

Sriraman, Bharath, \& Hadamard, Á. J. (2009). The characteristics of mathematical creativity.

Zentralblatt Fur Diktatik Der Mathematik, 41(1-2), 13-27. https://doi.org/10.1007/s11858-0080114-Z

Stoyanova, E., \& Ellerton, N. F. (1996). A framework for research into students' problem posing in school mathematics. In P. Clarkson (Ed.), Technology in mathematics education (pp. 518-525). Melbourne: Mathematics Education Research Group of Australasia.

Voica, C., \& Mihaela, F. (2012). Creative contexts as ways to strengthen mathematics learning. $\begin{array}{llll}\text { Procedia-Social And } \quad \text { Behavioral } & \text { Science, }\end{array}$ https://doi.org/10.1016/j.sbspro.2012.01.179

Wang, Y. (2009). On Cognitive Foundations of Creativity and the Cognitive Process of Creation. International Journal of Cognitive Informatics And Natural Intelligence, 3(4), 1-18. https://doi.org/10.4018/jcini.2009062301

Yuan, X., \& Sriraman, B. (2011). An axploratory study of relationship between students' creativity and mathematical problem-posing abilities. In B Sriraman \& K. . Lee (Eds.), The elemen of Creativity and Giftedness in Mathematics. Netherlands: Sense Publisher.

Zakaria, E., \& Salleh, F. (2012). Teachers ' Creativity in Posing Statistical Problems from Discrete Data. Creative Education, 3(8), 1380-1383. 